\title{
Comparison of enalapril and nifedipine in treating non-insulin dependent diabetes associated with hypertension: one year analysis
}

\author{
J C N Chan, C S Cockram, M G Nicholls, C K Cheung, R Swaminathan
}

Departments of Clinical Pharmacology, Medicine, and Chemical Pathology, Chinese University of Hong Kong, Prince of Wales Hospital, Shatin, Hong Kong

J C N Chan, lecturer C S Cockram, reader M G Nicholls, professor C K Cheung, scientific officer R Swaminathan, professor

Correspondence to: Dr J C N Chan, Department of Clinical Pharmacology, Prince of Wales Hospital, Shatin, NT, Hong Kong.

$B M \mp 1992 ; 305: 981-5$

\begin{abstract}
Objectives-To compare the efficacy, safety, and tolerance of enalapril and nifedipine in hypertensive patients with non-insulin dependent diabetes.

Design-One year double blind follow up of patients randomly allocated to either enalapril or nifedipine with matching placebos for the alternative drug.
\end{abstract}

Setting-Metabolic Investigation Unit, Hong Kong.

Subjects-102 patients were randomised: 52 to nifedipine and 50 to enalapril. At baseline 44 patients had normoalbuminuria, 36 microalbuminuria, and 22 macroalbuminuria.

Main outcome measures-Blood pressure, albuminuria, and parameters of renal function and glycaemic control.

Results-In patients who completed one year's treatment the median dose required by the nifedipine group $(n=49)$ was $60 \mathrm{mg} /$ day; seven $(14 \%)$ required additional diuretics. Of 41 patients given enalapril, 37 required the maximum dose $(40 \mathrm{mg} /$ day) and 27 $(76 \%)$ required diuretics. At one year mean arterial blood pressures were similar in both groups. Albuminuria fell by $54 \%$ in the enalapril group and $11 \%$ in the nifedipine group $(p=0 \cdot 006)$. Fractional albumin clearance ratio fell by $47 \%$ in the enalapril group and increased by $3 \%$ in the nifedipine group $(p=0.009)$. Creatinine clearance fell similarly in both groups but plasma creatinine concentration was increased by $20 \%$ in the enalapril group versus $8 \%$ in the nifedipine group $(p=0 \cdot 001)$.

Conclusion-Patients taking enalapril often required diuretics to control blood pressure. Enalapril reduced proteinuria significantly more than nifedipine in the microalbuminuric and macroalbuminuric patients but increased plasma creatinine concentrations. Longer follow up is required to clarify the importance of enalapril's antiproteinuric effect.

\section{Introduction}

Early aggressive antihypertensive treatment has been associated with a reduction in the rate of

TABI.E I-Study protocol for randomised trial of enalapril and nifedipine in hypertensive patients with noninsulin dependent diabetes

\begin{tabular}{|c|c|c|c|c|c|c|c|c|c|c|}
\hline Weeks & $\mid \stackrel{-6}{\leftarrow \text { Place }}$ & $\begin{array}{l}-4 \\
\mathrm{ebo} \rightarrow 1\end{array}$ & $\stackrel{0}{\longleftarrow}$ & 4 & 8 & $\begin{array}{c}12 \\
\text { Active }\end{array}$ & $\begin{array}{l}16 \\
\text { treatment }\end{array}$ & 24 & 36 & 52 \\
\hline 24 Hour urine collection & $\uparrow$ & $\uparrow$ & $\uparrow$ & $\uparrow$ & $\uparrow$ & $\uparrow$ & $\uparrow$ & $\uparrow$ & $\uparrow$ & $\uparrow \uparrow$ \\
\hline $\begin{array}{l}\text { Enalapril } \\
\text { or }\end{array}$ & & & & 10 & 20 & 40 & & & & \\
\hline $\begin{array}{l}\text { Nifedipine (modified release) } \\
\text { Indapamide } \\
\text { or }\end{array}$ & & & & 40 & 60 & 80 & 2.5 & & & \\
\hline Frusemide & & & & & & & & 40 & 80 & 120 \\
\hline
\end{tabular}

*Patients received a matching placebo for the alternative drug. deterioration in kidney function in patients with insulin dependent diabetes mellitus. ${ }^{\text {Angiotensin II }}$ has potent vasoconstrictive effects on the efferent renal arteriole ${ }^{2} ;$ thus angiotensin converting enzyme inhibitors might reduce filtration pressure and preserve renal function more successfully than alternative antihypertensive drugs. Indeed, animal data suggest that this may be so. ${ }^{3+}$ The antiproteinuric and renal protective effects of long term treatment with angiotensin converting enzyme inhibitors have recently been reported in insulin dependent diabetes. ${ }^{5}$ Nevertheless, non-insulin dependent diabetes, which is the more prevalent form of diabetes, particularly among non-whites, ${ }^{6}$ contributes importantly to the patient population with end stage renal failure. ${ }^{7}$ To date, only a few clinical trials have studied the effects of angiotensin converting enzyme inhibitors in patients with non-insulin dependent diabetes and the results have been inconclusive. ${ }^{8-10}$

We conducted a study to compare the long term effects of the angiotensin converting enzyme inhibitor enalapril with the calcium channel blocker nifedipine in the treatment of non-insulin dependent diabetes associated with hypertension.

\section{Patients and methods}

STUDY PROTOCOL

The study was approved by the ethics committee of the Chinese University of Hong Kong. Informed consent was obtained from all participants. Table I outlines the study design.

Patients with non-insulin dependent diabetes treated by diet or oral hypoglycaemic drugs, or both, who were either hypertensive or receiving antihypertensive drugs and who were attending the outpatient diabetic clinic at our hospital were invited to participate in the study. All patients were Chinese and aged over 18. Patients were excluded if they were receiving insulin or had a history of non-diabetic renal disease, appreciable renal impairment (plasma creatinine concentration $\geqslant 200 \mu \mathrm{mol} / \mathrm{l}$ ), a plasma potassium concentration $\geqslant 5$ $\mathrm{mmol} / \mathrm{l}$, cardiac failure or any concurrent systemic disease, or were receiving treatment for any concomitant disorder.

Previous antihypertensive drugs were discontinued and patients received placebo tablets to match enalapril $10 \mathrm{mg}$ once daily and modified release nifedipine $20 \mathrm{mg}$ twice daily. All patients were maintained on diets previously prescribed as part of their routine medical care. At the end of the six week run in period patients who satisfied the inclusion blood pressure criteria and none of the above exclusion criteria were admitted to the study. Inclusion blood pressure criteria were a mean supine systolic blood pressure of $150-220 \mathrm{~mm} \mathrm{Hg}$ or a diastolic blood pressure (phase V) greater than 100 $\mathrm{mm} \mathrm{Hg}$, or both, at three readings during the run in period. Patients were then assigned to receive either 
enalapril or modified release nifedipine with matching placebo tablets for the alternative drug according to a random allocation schedule. A schedule of 102 allocation numbers corresponding to similarly numbered drug supplies was provided for this purpose. Both the patients and the staff measuring blood pressure and biochemical indices were blinded to treatment.

Based on the mean value of three measurements of 24 hour urinary albumin excretion during the run in period, 44 patients had normoalbuminuria ( $<30 \mathrm{mg} /$ day), 36 microalbuminuria (30-300 mg/day), and 22 macroalbuminuria $\left(>300 \mathrm{mg} /\right.$ day).$^{17}$

Drug doses were increased over 12 weeks to a maximum of enalapril $40 \mathrm{mg}$ once daily or nifedipine $40 \mathrm{mg}$ twice daily if supine systolic blood pressure remained above $140 \mathrm{~mm} \mathrm{Hg}$ (table I). Indapamide 2.5 $\mathrm{mg} /$ day was added if the blood pressure remained high and, if necessary, this was replaced by frusemide (up to $120 \mathrm{mg} /$ day) to achieve the target supine systolic blood pressure. Follow up visits were scheduled between $8 \mathrm{am}$ and $10 \mathrm{am}$, at which time the blood pressure was measured, and venous blood was sampled for measurements of renal function, glycated haemoglobin, plasma fructosamine, and fasting plasma glucose concentration, and serum angiotensin converting enzyme activity. Twenty four hour urine samples were collected for estimation of albumin excretion. At the end of one year two 24 hour urine samples were collected within two weeks.

\section{MEASUREMENTS}

Blood pressure was measured by a single research nurse using a Hawksley random zero sphygmomanometer after the patient had rested for five minutes in the supine position and also after two minutes of standing. The mean of two readings for each body position was recorded. Mean arterial blood pressure was calculated as diastolic blood pressure plus one third of the difference between systolic and diastolic blood pressure and was shown as a mean of supine and standing values unless otherwise stated. All urine samples were stored at $4^{\circ} \mathrm{C}$ and analysed within one

TABLE II-Clinical characteristics of patients and mean biochemical data from the last two visits of the rum in period. Values are means (SD) unless stated otherwise

\begin{tabular}{|c|c|c|}
\hline & $\begin{array}{l}\text { Nifedipine } \\
\text { group } \\
(\mathrm{n}=52)\end{array}$ & $\begin{array}{l}\text { Enalapril } \\
\text { group } \\
(\mathrm{n}=50)\end{array}$ \\
\hline No of men & 21 & 20 \\
\hline No of women & 31 & 30 \\
\hline Age (years) & $56 \cdot 1(9 \cdot 9)$ & $60 \cdot 1(9 \cdot 2)$ \\
\hline Duration of diabetes (years) & $5 \cdot 6(4 \cdot 6)$ & $5 \cdot 5(4 \cdot 8)$ \\
\hline Duration of hypertension (years) & $5 \cdot 3(4 \cdot 7)$ & $5 \cdot 6(5 \cdot 3)$ \\
\hline No $(\%)$ with retinopathy & $22(42)$ & $17(34)$ \\
\hline No $(\%)$ with neuropathy & $14(27)$ & $15(30)$ \\
\hline Body mass index $\left(\mathrm{kg} / \mathrm{m}^{5}\right)$ & $24 \cdot 8(3 \cdot 0)$ & $25 \cdot 2(2 \cdot 9)$ \\
\hline Supine blood pressure $(\mathrm{mm} \mathrm{Hg})$ & $166 / 91(16 / 9)$ & $174 / 92(17 / 13)$ \\
\hline Erect blood pressure $(\mathrm{mm} \mathrm{Hg})$ & $167 / 94(16 / 12)$ & $171 / 94(19 / 14)$ \\
\hline Mean arterial blood pressure $(\mathrm{mm} \mathrm{Hg})$ & $117(9)$ & $120(12)$ \\
\hline Glycated haemoglobin $(\%)$ & $9 \cdot 8(1 \cdot 7)$ & $10 \cdot 4(1 \cdot 7)$ \\
\hline Plasma fructosamine $(\mathrm{mmol} / \mathrm{l})$ & $2 \cdot 3(0.23)$ & $2 \cdot 3(0 \cdot 23)$ \\
\hline Fasting plasma glucose $(\mathrm{mmol} / \mathrm{l})$ & $8 \cdot 0(2 \cdot 1)$ & $8 \cdot 3(2 \cdot 5)$ \\
\hline $\begin{array}{l}\text { Geometric mean (antilog SD) plasma } \\
\text { creatinine }(\mu \mathrm{mol} / \mathrm{l})\end{array}$ & $80 \cdot 9(1 \cdot 4)$ & $83 \cdot 0(1 \cdot 3)$ \\
\hline $\begin{array}{l}\text { Geometric mean (antilog SD) urinary } \\
\text { albumin excretion (mg/day) }\end{array}$ & $69 \cdot 5(6 \cdot 8)$ & $64 \cdot 7(6 \cdot 6)$ \\
\hline $\begin{array}{l}\text { Geometric mean (antilog SD) creatinine } \\
\text { clearance }(\mathrm{ml} / \mathrm{min})\end{array}$ & $70 \cdot 0(1 \cdot 6)$ & $65.5(1.5)$ \\
\hline $\begin{array}{l}\text { Geometric mean (antilog SD) fractional } \\
\text { albumin clearance ratio }\left(\times 10-^{6}\right)\end{array}$ & $15 \cdot 2(9 \cdot 6)$ & $15 \cdot 3(7 \cdot 4)$ \\
\hline
\end{tabular}

TABLE III-Severity of proteinuria at baseline and the number of patients who completed one year of treatment in each category

\begin{tabular}{lccccccc}
\hline & $\begin{array}{c}\text { Urinary albumin } \\
\text { excretion } \\
\text { Category }\end{array}$ & & \multicolumn{2}{c}{ Nifedipine group } & & \multicolumn{2}{c}{ Enalapril group } \\
& $(\mathrm{mg} /$ day $)$ & Week 0 & Week 52 & & Week 0 & Week 52 \\
\hline Normoalbuminuria & $<30$ & & 24 & 24 & & 20 & 18 \\
Microalbuminuria & $30-300$ & 15 & 15 & & 21 & 16 \\
Macroalbuminuria & $>300$ & 13 & 10 & & 9 & 7 \\
\hline
\end{tabular}

week of collection for albumin concentration by immunoturbidimetry using a modification of a published technique. ${ }^{18}$ Intra-assay and interassay coefficients of variation were $3.3 \%$ and $6.7 \%$ respectively within the range $1 \cdot 2-80 \mathrm{mg} / \mathrm{l}$. The lowest detection limit was $1.2 \mathrm{mg} / 1$. Plasma and urine creatinine concentrations were measured by the Jaffe method on an Astra-8 Chemistry Analyser (Beckman Instrument, Palo Alto, California). Glycated haemoglobin concentration $\left(\mathrm{HbA}_{1}\right)$ was measured by gel electrophoresis (Ciba Corning Diagnostics, Alto, California) with a reference range of $6 \cdot 5-8 \cdot 5 \%$. Plasma glucose concentration was measured by a glucose oxidase method (Diagnostic Chemicals reagent kit) and plasma fructosamine, by published methods. ${ }^{19}$. Serum angiotensin converting enzyme activity was measured by a modified spectrophotometric method ${ }^{20}$ and the intra-assay and interassay coefficients of variation were less than $5 \%$.

For presentation of skewed data that were analysed as logarithms, the mean was back transformed (antilogged) to give the geometric mean and the 95\% confidence intervals obtained for the mean of the $\log$ data were also antilogged.

\section{STATISTICS}

The study required 51 patients in each treatment group to have a $90 \%$ power at the $5 \%$ level (two tailed) to show that one drug was at least twice as effective as the other in reducing urinary albumin excretion. The mean (SD) or geometric mean (antilog of SD) values for all variables measured during the last two visits of the run in period were taken as baseline values. Doses of drugs administered are given as median. Fractional albumin clearance ratios were calculated as 24 hour urinary albumin concentration $\times$ plasma creatinine concentration/plasma albumin concentration $\times 24$ hour urinary creatinine concentration. Plasma creatinine concentration, creatinine clearance, fractional albumin clearance ratio, and urinary albumin excretion and serum angiotensin converting enzyme concentration were $\log$ transformed before analysis because of skewed distributions. The mean value from two measurements of urinary albumin excretion, fractional albumin clearance ratio, and creatinine clearance estimated at the end of one year were compared with baseline values and differences were compared between treatment groups. Mean (95\% confidence interval) differences between the two treatment groups were examined by Student's two tailed $t$ test. The antilog of a difference between two means was transformed into relative changes expressed as ratios compared with baseline values with $95 \%$ confidence intervals. Fisher's exact test was used to compare the rates of conversion from normoalbuminuria to abnormal albuminuria between the treatment groups. Repeated measures analysis of variance was used to test for the effects of treatment and its duration. Only data from patients who completed the one year study were included for these comparisons. Statistical analysis was performed with the packages ABstat (Anderson-Bell, Colorado, United States, 1989) and SPSS. Significance was taken as $\mathrm{p}<0.05$ (two tailed).

\section{Results}

POPULATION CHARACTERISTICS

Of 123 patients recruited, 102 fulfilled all inclusion criteria and were randomised to active treatment. Table II shows the baseline clinical characteristics and mean biochemical data from the last two visits of the run in period. Table III shows the level of albuminuria at baseline and the number of patients who completed one year of treatment in the subgroups. Forty nine of 


\begin{tabular}{|c|c|c|c|c|}
\hline & Whole group & Normoalbuminuria & Microalbuminuria & Macroalbuminuria \\
\hline \multicolumn{5}{|c|}{ Urinary albumin excretio: $*$ : } \\
\hline Enalapril & $0.46(0.32$ to 0.67$)$ & $0.88(0.59$ to 1.34$)$ & $0.27(0.15$ to 0.46$)$ & $0.29(0.11$ to 0.77$)$ \\
\hline Nifedipine & $0.89(0.66$ to 1.2$)$ & $0.81(0.55$ to 1.2$)$ & $0.85(0.43$ to 0.88$)$ & $1.15(0.85$ to 1.54$)$ \\
\hline $\mathrm{p}$ Value & 0.006 & 0.751 & $0 \cdot 013$ & 0.006 \\
\hline \multicolumn{5}{|c|}{ Fractional albumin clearance ratio ${ }^{\star}$ : } \\
\hline Enalapril & $0.53(0.37$ to 0.77$)$ & $0.95(0.58$ to 1.72$)$ & $0.28(0.18$ to 0.44$)$ & $0.38(0.16$ to 0.88$)$ \\
\hline Nifedipine & $1.03(0.75$ to 1.43$)$ & $0.96(0.63$ to 1.45$)$ & $0.99(0.43$ to 2.3$)$ & $1.3(1$ to 1.66$)$ \\
\hline $\mathrm{p}$ Value & 0.009 & 0.773 & 0.012 & 0.005 \\
\hline \multicolumn{5}{|c|}{ Creatinine clearance ${ }^{\star}$ : } \\
\hline Enalapril & $0.85(0.75$ to 0.97$)$ & $0.86(0.72$ to 1.03$)$ & $0 \cdot 89 \cdot(0 \cdot 71$ to $1 \cdot 1)$ & $0.76(0.52$ to 1.12$)$ \\
\hline Nifedipine & $0.85(0.79$ to 0.92$)$ & $0.85(0.77$ to 0.93$)$ & $0.88(0.75$ to 1.04$)$ & $0.83(0.7$ to 0.98$)$ \\
\hline p Value & 0.989 & 0.841 & $0 \cdot 989$ & 0.675 \\
\hline \multicolumn{5}{|c|}{ Plasma creatinine ${ }^{\star}$ : } \\
\hline Enalapril & $1 \cdot 2(1 \cdot 14$ to $1 \cdot 26)$ & $1.15(1.09$ to 1.23$)$ & $1.26(1.17$ to 1.36$)$ & $1.17(0.98$ to 1.4$)$ \\
\hline Nifedipine & $1.08(1.05$ to 1.12$)$ & $1.06(1.01$ to 1.12$)$ & $1.06(1.01$ to 1.1$)$ & $1.19(1.08$ to 1.3$)$ \\
\hline p Value & 0.001 & 0.034 & $<0.001$ & 0.904 \\
\hline \multicolumn{5}{|c|}{ Mean arterial pressuret: } \\
\hline Enalapril & $-21 \cdot 2(-24 \cdot 8$ to $-16 \cdot 3)$ & $-18 \cdot 9(-24 \cdot 1$ to $-13 \cdot 8)$ & $-21 \cdot 6(-29 \cdot 2$ to $-13 \cdot 9)$ & $-22 \cdot 0(-34 \cdot 3$ to $-9 \cdot 7)$ \\
\hline Nifedipine & $-20 \cdot 1(-24 \cdot 1$ to $-18 \cdot 4)$ & $-17 \cdot 5(-20 \cdot 9$ to $-14 \cdot 1)$ & $-25 \cdot 1(-31 \cdot 1$ to $-19 \cdot 1)$ & $-24 \cdot 5(-29 \cdot 5$ to $-19 \cdot 4)$ \\
\hline $\mathrm{p}$ Value & 0.759 & 0.633 & $0 \cdot 481$ & 0.685 \\
\hline
\end{tabular}

* Mean relative change expressed as ratios compared with baseline values (95\% confidence intervals).

tMean difference ( $95 \%$ confidence intervals)

p Values are for comparisons between changes in the two treatment groups (Student's two tailed $t$ test).

TABLE V-Mean (95\% confidence interial) changes in glycaemic indices during 52 weeks' treatment with enalapril or nifedipine

\begin{tabular}{llll}
\hline Glycaemic index & \multicolumn{1}{c}{$\begin{array}{c}\text { Enalapril } \\
\text { group }\end{array}$} & \multicolumn{1}{c}{$\begin{array}{c}\text { Nifedipine } \\
\text { group }\end{array}$} & p Value \\
\hline Glycated haemoglobin $(\%)$ & $0.63(-0.2$ to $1 \cdot 47)$ & $0.12(-0.3$ to 0.57$)$ & 0.253 \\
Plasma fructosamine $(\mathrm{mmol} / 1)$ & $0.14(0.0$ to $0 \cdot 27)$ & $0.00(-0.07$ to 0.09$)$ & 0.089 \\
Plasma glucose $(\mathrm{mmol} / \mathrm{l})$ & $0.42(-0.6$ to $1 \cdot 5)$ & $0.48(-0.8$ to 1.7$)$ & 0.93 \\
\hline
\end{tabular}

the 52 patients randomised to nifedipine completed one year of treatment compared with 41 of 50 randomised to enalapril. Of the nine patients taking enalapril who did not complete one year, three were withdrawn because of cough, three were withdrawn because of inadequate control of blood pressure, one died of myocardial infarction, one developed angina, and one defaulted. Of the three patients who received nifedipine, one had inadequate blood pressure control, one had angina, and one had tuberculous lymphadenitis.
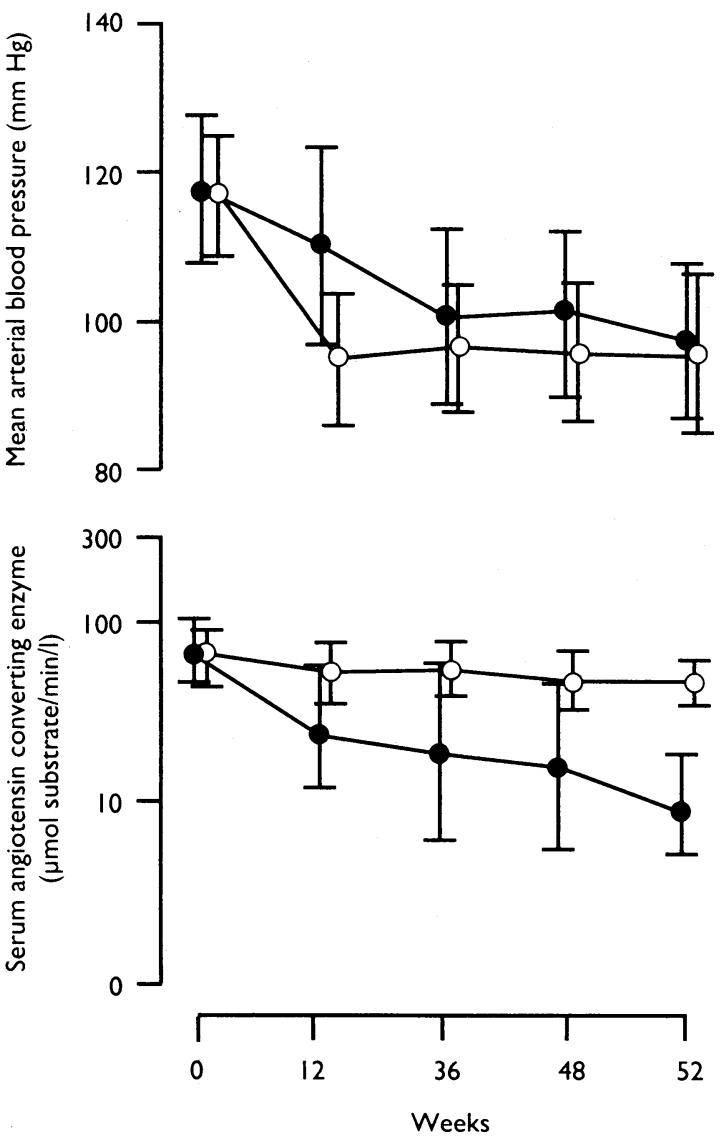

BLOOD PRESSURE, BODY WEIGHT, AND GI.YCAEMIC CONTROL

At one year, $90 \%(37 / 41)$ of the patients receiving enalapril required the maximum dose of enalapril ( 40 $\mathrm{mg} /$ day) and $76 \%$ (31/41) required the addition of diuretic treatment (20 took indapamide and 11 frusemide). The median dose of nifedipine was $60 \mathrm{mg} /$ day and $14 \%$ of patients (7/49) required additional diuretics (four indapamide and three frusemide). Although at one year the reduction in and the achieved levels of mean arterial pressures were similar in both treatment groups (table IV), blood pressure was significantly higher overall in the enalapril group than in the nifedipine group $(p<0.001$ for drug difference, $p<0.001$ for time trend, and $p=0.001$ for time and drug interaction). The relative change in serum angiotensin converting enzyme activity was significantly greater in patients receiving enalapril $(0 \cdot 12(95 \%$ confidence interval $0 \cdot 1$ to $0 \cdot 15)$ ) than in those receiving nifedipine $(0.71(0.63$ to 0.81$), \mathrm{p}<0.001$; fig 1$)$.

Body mass index fell by $0.28(-0.58$ to 0.01$) \mathrm{kg} / \mathrm{m}^{2}$ over 12 months in the enalapril group and $0 \cdot 25(-0.48$ to $-0 . \cap 2) \mathrm{kg} / \mathrm{m}^{2}$ in the nifedipine group $(\mathrm{p}=0.841)$. The haemoglobin concentration fell by $7.5(-11.5$ to -3.6) $\mathrm{g} / \mathrm{l}$ in the enalapril group compared with a reduction of $2.4(-0.5$ to 0.6$) \mathrm{g} / \mathrm{l}$ in the nifedipine group ( $p=0.035)$. At week 4 , before the addition of diuretics, the plasma glucose concentration had fallen by $0.98(-1.7$ to -0.31$) \mathrm{mmol} / \mathrm{l}$ in the patients receiving enalapril compared with $0.09(-0.57$ to 0.38$)$ $\mathrm{mmol} / \mathrm{l}$ in those receiving nifedipine $(\mathrm{p}=0.033)$. However, glycaemic indices were similar in the two treatment groups at one year and overall changes were not significantly different between the groups (table V).

\section{ALBUMINURIA AND RENAL FUNCTION}

Table IV summarises changes in mean arterial blood pressure, urinary albumin excretion, fractional albumin clearance ratio, creatinine clearance, and plasma creatinine concentration in the two treatment groups. Treatment with enalapril reduced proteinuria, and the fractional albumin clearance ratio significantly more than treatment with nifedipine, in all patients and also in the microalbuminuric and macroalbuminuric groups separately. In normoalbuminuric patients, urinary albumin excretion remained less than $30 \mathrm{mg} /$ day in all of the 18 patients given enalapril whereas two of the 23 patients receiving nifedipine developed abnormal albuminuria $(p=0 \cdot 621)$. Figure 2 shows changes in urinary albumin excretion in individual patients during one year of treatment. Creatinine clearance fell to a similar extent in both 
TABI: VI-The effects of additional diuretic on renal function and blood pressure in patients receiving enalapril

\begin{tabular}{|c|c|c|}
\hline & $\begin{array}{l}\text { No diuretics } \\
(n=10)\end{array}$ & $\begin{array}{l}\text { Diuretics } \\
(\mathrm{n}=31)\end{array}$ \\
\hline $\begin{array}{l}\text { Mean }(95 \% \text { confidence interval) arterial pressure } \\
(\mathrm{mm} \mathrm{Hg})\end{array}$ & $-20 \cdot 1(-28.9$ to $-11 \cdot 1)$ & $-20 \cdot 6(-25 \cdot 5$ to $-15 \cdot 8)$ \\
\hline Urinary albumin excretion rate ${ }^{\star}$ & $0.65(0.38$ to 1.09$)$ & $0.42(0.27$ to 0.65$)$ \\
\hline Fractional albumin clearance ratio $\left(\times 10^{6}\right)^{\star}$ & $0.77(0.34$ to 1.71$)$ & $0.47(0.31$ to 0.71$)$ \\
\hline Plasma creatinine $(\mu \mathrm{mol} / \mathrm{l})^{\star}$ & $1.08(0.98$ to 1.18$)$ & $1.24(1.18$ to 1.31$) \dagger$ \\
\hline Creatinine clearance $(\mathrm{ml} / \mathrm{min})^{\star}$ & $0.90(0.67$ to 1.2$)$ & $0.84(0.72$ to 0.97$)$ \\
\hline
\end{tabular}

$\star$ Mean relative change expressed as ratios compared with baseline values $(95 \%$ confidence intervals). $t p=0 \cdot 011$

\section{Discussion}

Considerable attention has been directed to the potential renal protective effects of angiotensin converting enzyme inhibitors in insulin dependent diabetes, and recent data suggest that these drugs may slow the rate of decline in glomerular filtration rate more effectively than $\beta$ adrenoceptor blocking drugs. ${ }^{5}$ Although non-insulin dependent diabetes is the more prevalent form of diabetes, particularly among nonwhites, ${ }^{\circ}$ and accounts for a considerable proportion of patients with end stage renal disease, ${ }^{7}$ few trials have been reported comparing angiotensin converting enzyme inhibitors with alternative antihypertensive drugs in such patients. ${ }^{\mathrm{s}-16}$ Some of the longer term studies suggest there is little difference between antihypertensive drugs with regard to their effects on urinary protein excretion ${ }^{\mathrm{x}-15}$ whereas Ferder et al reported that enalapril had a superior antiproteinuric action to nifedipine in hypertensive patients. ${ }^{16} \mathrm{We}$ studied a homogeneous population of 102 Chinese patients with hypertension and non-insulin dependent diabetes to compare the effects of an angiotensin converting enzyme inhibitor, enalapril, with a calcium channel blocker, nifedipine, on blood pressure, renal function, and glycaemic control.

The antihypertensive effects of treatment with enalapril and nifedipine were similar at one year, but the fall in blood pressure was slower with the angiotensin converting enzyme inhibitor, as has been reported previously in elderly white patients with essential hypertension. ${ }^{21}$ Furthermore, more patients receiving enalapril required a diuretic to achieve the goal systolic blood pressure $(140 \mathrm{~mm} \mathrm{Hg}$ in the supine position) than patients receiving nifedipine. These apparent differences in antihypertensive effectiveness might reflect the fact that full comparative dose response (drug and blood pressure) curves were not assessed, that the full antihypertensive action of enalapril may require more than 12 weeks to develop under the conditions of the study, and that racial factors might modify the antihypertensive efficacy of the drugs chosen-as is the case for $\beta$ adrenoceptor blockers and diuretics in black, compared with white, patients. ${ }^{22}$

\section{ALBUMINURIA}

Despite a higher overall level of blood pressure, patients receiving enalapril showed the greater fall in urinary albumin excretion. A significant antiproteinuric action of enalapril, compared with nifedipine, was observed in patients who initially exhibited macroalbuminuria or microalbuminuria. The rates of conversion from normoalbuminuria to microalbuminuria were not different between the two study groups after one year. As diuretics were required by most patients receiving enalapril it is possible that the diuretics, rather than the angiotensin converting enzyme inhibitor, accounted for the fall in urinary albumin excretion, especially since indapamide has recently been shown to have an antiproteinuric action in hypertensive non-insulin dependent diabetic patients. ${ }^{23}$ Further analysis of our data, however, showed similar antiproteinuric effects of enalapril whether or not a diuretic was added. Our data, therefore, agree with the findings of Ferder et al, who reported that fixed dose enalapril $(40 \mathrm{mg} /$ day $)$ for one year in 18 hypertensive non-insulin dependent diabetic patients reduced urine excretion significantly whereas fixed dose nifedipine ( $40 \mathrm{mg} /$ day) failed to alter urinary protein output in 12 patients. ${ }^{16}$

Endogenous creatinine clearance fell to a similar extent in the two treatment groups. By contrast, plasma creatinine rose to a greater extent in patients treated with enalapril. This discrepancy may be largely due to the greater coefficient of variation inherent in 
the measurement of endogenous creatinine clearance, as it is dependent not only on determination of plasma creatinine concentrations but also on measurements of urinary creatinine concentration and urine volume. ${ }^{2+}$ Further analysis of our data showed that plasma creatinine concentrations rose more in patients taking enalapril who received concomitant diuretics than in patients taking only enalapril. The higher plasma creatinine concentration in the enalapril group might therefore reflect the greater number of patients requiring a diuretic. In severe cardiac failure the combination of a diuretic and angiotensin converting enzyme inhibitor often induces a rise in plasma creatinine concentration $^{25-2 i}$ which, on prolonged treatment, usually falls again. ${ }^{25}$ Björck et al also reported an early fall in glomerular filtration rate in patients with insulin dependent diabetes after the introduction of enalapril but stabilisation occurred after six months. ${ }^{5}$ Whether such a biphasic pattern in glomerular filtration rate occurs in our patients, remains to be seen.

\section{EFFECT ON GLYCAEMIC CONTROL AND HAEMOGLOBIN}

Hypoglycaemia consequent on initiation of treatment with angiotensin converting enzyme inhibitors has been reported in both insulin dependent and noninsulin dependent diabetic patients. ${ }^{28-30}$ Furthermore, the angiotensin converting enzyme inhibitors have been shown to improve insulin sensitivity, ${ }^{31}$ perhaps as a result of the accumulation of bradykinin, which has an insulin-like action. ${ }^{32}$ Early in our study, the mean fasting plasma glucose concentration fell significantly in patients receiving enalapril, but not in those receiving nifedipine. Subsequent indices of glycaemic control were similar in the two groups, presumably because the addition of diuretics, which are known to worsen glucose tolerance, ${ }^{30}$ countered any beneficial effect of the angiotensin converting enzyme inhibitor.

We observed a small but significant fall in haemoglobin concentration during treatment with enalapril. Angiotensin converting enzyme inhibitors have also been noted to reduce haemoglobin concentration in patients with insulin dependent diabetes, ${ }^{5}$ congestive heart failure, chronic renal failure, and kidney transplants. ${ }^{33}$ This effect may be partly due to a fall in angiotensin II concentration, which is known to stimulate erythropoietin under certain circumstances. ${ }^{334}$

Chinese hypertensive patients with non-insulin dependent diabetes treated with enalapril often required additional diuretic therapy to control blood pressure. Despite similar blood pressure responses in the two groups at the end of one year, enalapril reduced proteinuria more effectively than nifedipine. The reduction in proteinuria occurred in patients with both microalbuminuria and macroalbuminuria. Plasma creatinine concentration increased in both groups but to a greater extent in the enalapril group, particularly in those requiring diuretics. Withdrawal from the study was more common with enalapril, mostly because of cough or inadequate control of blood pressure. A longer period of treatment is required to establish the significance of the reduction of proteinuria with enalapril and to determine whether this will be translated into a beneficial effect on glomerular filtration rate. Our study will continue for a further two years. Until more information is available it is premature, in our view, to suggest that any one group of antihypertensive drugs is superior to any other in the treatment of non-insulin dependent diabetes associated with hypertension.

The study was sponsored by Merck, Sharpe, and Dohme. We thank Ms Margaret Cheung and Ms Angela Wong, ou two research nurses for their dedication; Dr Denis Leung from the Centre for Clinical Trials and Epidemiological
Research, Chinese University of Hong Kong, for help with the statistical analysis; and Dr J A J H Critchley, reader of the department of clinical pharmacology, Chinese University of Hong Kong, for critical appraisal of the manuscript.

1 Parving HH, Andersen AR, Smidt UM, Svendsen PAa. Early aggressive antihypertensive treatment reduces rate of decline in kidney function in antihypertensive treatment reduces rate of

2 Hella J, Horacek V. Angiotensin II: preferential efferent constriction. Renal Physiol 1986;9:357-65

3 Jackson B, Johnston CI. The contribution of systemic hypertension to progression of chronic renal failure in the rat remnant kidney: effect of treatment with an ACE inhibitors or a calcium inhibitor. $\mathcal{f}$ Hyperten 1988;6:495-501.

4 Myers BD, Meyer TW. Angiotensin-converting enzyme inhibitors in the prevention of experimental diabetic glomerulopathy. Am f Kidney $D_{l}$ 1989;13:20-4.

5 Björck S, Mulec H, Johnsen SA, Nórden G, Aurell M. Renal protective effect of enalapril in diabetic nephropathy. $B M \mathcal{F}$ 1992;304:339-43.

6 Zimmet P. Type 2 (non-insulin-dependent) diabetes-an epidemiological overview. Diabetologia 1982;22:399-411.

7 Mogensen CE. Angiotensin converting enzyme inhibitors and diabetic nephropathy BM71992:304:327-8.

8 Melbourne Diabetic Nephropathy Study Group. Comparison between perindopril and nifedipine in hypertensive and normotensive diabetic patients with microalbuminuria. BMF 1991;302:210-6.

9 Baba T, Murabayashi S, Takebe $\mathrm{K}$. Comparison of the renal effects of $\mathrm{ACE}$ inhibitors and calcium antagonist in hypertensive type 2 (non-insulindependent) diabetic patients with microalbuminuria: a randomized controlled trial. Diabetologia 1989;32:40-4.

10 Valvo E, Bedogna V, Casagrande P, Antiga L, Zamboni M, Bommartini $F$ ct al. Captopril in patients with type II diabetes and renal insufficiency. systemic and renal hemodynamic alterations. Am f Med 1988;85:344-8.

11 Stornello M, Valvo EV, Vasques E, Leone S, Scapellato L. Systemic and rena effects of chronic angiotensin converting enzyme inhibition with captopril in hypertensive diabetic patients. $\mathcal{F}$ Hypertens 1989;7(suppl): PS65-7.

12 Ueda Y, Aoi W, Yamachika S, Shikaya T. Beneficial effects of angiotensinconverting enzyme inhibitor on renal function and glucose homeostasis in diabetics with hypertension. Nephron 1990;55(suppl 1):85-9.

13 Matthews DM, Wathen CG, Bell D, Collier A, Roulston JE, Clarke BF, et al. The use of captopril and captopril plus frusemide as antihypertensive agents in non-insulin dependent diabetes. 7 Hum Hypertens 1987;1:19-23.

14 Stornello M, Valvo EV, Scapellato L. Persistent albuminuria in normotensive non-insulin-dependent (type II) diabetic patients: comparative effects of angiotensin-converting enzyme inhibitors and $\beta$-adrenoceptor blockers. Clin Sci 1992;82:19-23.

15 Ferrier C, Ferrari P, Weidmann P, Keller U, Beretta-Piccoli C, Riesen WF Antihypertensive therapy with calcium antagonist, verapamil and/or $\mathrm{ACE}$ inhibitor enalapril in NIDDM patients. Diabetes Care 1991;14:911-4.

16 Ferder L, Daccordi H, Martello M, Panzalis M, Inserra F. Angiotensin converting enzyme inhibitors versus calcium antagonists in the treatment of diabetic hypertensive patients. Hypertension 1992;19(suppl II):237-42.

17 Rowe DJF, Dawnay A, Watts GF. Microalbuminuria in diabetes mellitus: review and recommendations for the measurement of albumin in urine. Ann Clin Biochem 1990;27:297-312.

18 Cheung CK, Swaminathan R. Automated immunoturbidimetric method for the determination of retinol binding protein, prealbumin and transferrin in urine Clin Biochem 1989;22:425-7.

19 MacDonald D, Pang CP, Cockram CS, Swaminathan R. Fructosamin measurements in serum and plasma. Clin Chem Acta 1987;168:247-52.

20 McGuire GA, Price CP. A continuous monitoring spectophotometric method for the measurement of ACE in human serum. Ann Clin Biochem 1985;22 204-10

21 Gilchrist NL, Nicholls MG, Ewer TC, Livesey JH, Sainsbury R. A comparison of long acting nifedipine and enalapril in elderly hypertensives: a randomised, single-blind, cross-over study. I Hum Hypertens 1988;2:33-9.

22 Veterans Administration Cooperative Study group on Antihypertensive Agents. Comparison of propranolol and hydrochlorthiazide for the initial treatment of hypertension. I. Results of short-term titration with emphasis on racial differences in response. IAMA 1982;248: 1996-2003.

23 Gambardella S, Frontoni S, Lala A, Felici MG, Spallone V, Scoppala A, et al. Regression of microalbuminuria in type II diabetic hypertensive patients Regression of microalbuminuria in type II diabetic hypertensive

24 Payne RB. Creatinine clearance: a redundant clinical investigation. Am Clin Biochem 1986;23:243-50.

25 Cleland JGF, Dargie HJ, Hodsman GP, Ball SG, Robertson JIS, Morton JJ, et al. Captopril in heart failure. A double blind controlled trial. Br Heart $\mathfrak{f}$ $1984 ; 52: 530-5$

26 Mujais SK, Fouad FM, Textor SC, Tarazi RC, Bravo EL, Hart N, et al. Transient renal dysfunction during initial inhibition of converting enzym in congestive heart failure. Br Heart $\mathcal{f}$ 1984;52:63-71.

27 Nicholls MG. Overview: angiotensin, angiotensin converting enzyme inhibition, and the kidney-congestive heart failure. Kidney Int 1987;3 (suppl 20):S200-2.

28 Ferriere M, Lachkar H, Richard J-L, Bringer J, Orsetti A, Mirouze J. Captopril and insulin sensitivity. Ann Intern Med 1985;102:134-5.

29 Arauz-Pacheco C, Ramirez LC, Rios J, Raskin P. Hypoglycemia induced by angiotensin-converting enzyme inhibitors in patients with non-insulinangiotensin-converting enzyme inhibitors in patients with non-insulin-
dependent diabetes receiving sulfonylurea therapy. Am $\mathcal{F}$ Med 1990;89: dependent $811-3$.

30 Chan JCN, Cockram CS. Drug-induced disturbances of carbohydrate metabolism. Adverse Drug Reactions Toxicological Review 1991;10:1-29.

31 Pollare T, Lithell H, Berne C. A comparison of the effects of hydrochlorothiazide and captopril on glucose and lipid metabolism in patient with hypertension. N Engl F Med 1989;321:868-73.

32 Jauch KW, Hartl W, Guenther B, Wicklmayr M, Rett K, Dietze G. Captopril enhances insulin responsiveness of forearm muscle tissue in non-insulindependent diabetes mellitus. Eur $\mathcal{F}$ Clin Invest 1987;17:448-54.

33 Lai KN, Lui SF. Renin and erythropoietin. In: Robertson JIS, Nicholls MG eds. Renin-angiotensin system textbook. London: Gower (in press).

34 Kamper A-L, Nielsen OJ. Effect of enalapril on hemoglobin and serum erythropoietin in chronic nephropathy. Scand f Clin Lab Invest 1990;50: 611-8.

(Accepted 20 August 1992) 